\title{
Smart University: A vision of technology adoption
}

\section{Universidad inteligente: Una visión de la adopción de la tecnología}

\author{
Dewar Rico-Bautista $^{1}$ (D), César D. Guerrero² ${ }^{\text {(D) }}$, César A. Collazos ${ }^{3}$ (D), Gina Maestre-Góngora ${ }^{4}$ (D), \\ Julio A. Hurtado-Alegría ${ }^{3}$ iD , Yurley Medina-Cárdenas ${ }^{1}$ (D), Jose Swaminathan ${ }^{5}$ \\ ${ }^{1}$ Universidad Francisco de Paula Santander, Ocaña, Colombia \\ ${ }^{2}$ Universidad Autónoma de Bucaramanga, Bucaramanga, Colombia \\ ${ }^{3}$ Universidad del Cauca, Popayán, Colombia \\ ${ }^{4}$ Universidad Cooperativa de Colombia, Medellín, Colombia \\ ${ }^{5}$ Vellore Institute of Technology, Vellore, India \\ dwricob@ufpso.edu.co,cguerrer@unab.edu.co,ccollazo@unicauca.edu.co, \\ gina.maestre@campusucc.edu.co,ahurtado@unicauca.edu.co,ycmedinac@ufpso.edu.co,jose.s@vit.ac.in
}

(Received: 5 February 2021; accepted: 12 May 2021; Published online: 1 June 2021)

\begin{abstract}
Smart University is an emerging concept, strongly anchored to smart technologies and considered by different authors in the literature. Organizations, including universities, need to incorporate smart technologies to take advantage of their capabilities to transform their processes and drive them toward new organizational models. A Smart University focuses on improving its technological infrastructure for achieving its quality educational goals. This paper presents the integration of the key factors for adopting four smart technologies: Cloud Computing, Big Data, Artificial Intelligence, and the Internet of Things. This characterization and integration allow us to conclude on the need to align digital technologies with the organization's processes, requiring greater interaction with the company's senior management.
\end{abstract}

Keywords: Digital technologies, Smart technologies, Smart university, Technology adoption.

Resumen. Universidad inteligente es un concepto emergente, fuertemente anclado a las tecnologías inteligentes, y considerado por diferentes autores en la literatura. Las organizaciones, incluidas las universidades, necesitan incorporar las tecnologías inteligentes para aprovechar las capacidades que proporcionan para transformar sus procesos e impulsarlas hacia nuevos modelos organizativos. Una universidad inteligente se centra en la mejora de su infraestructura tecnológica para lograr sus objetivos educativos de calidad. Este trabajo presenta la integración de los factores clave para la adopción de cuatro tecnologías inteligentes: Computación en la nube, Big Data, Inteligencia Artificial, e Internet de las Cosas. Esta caracterización e integración nos permite concluir sobre la necesidad de alineación de las tecnologías digitales con los procesos de la organización, exigiendo una mayor interacción con la alta dirección de la empresa.

Palabras clave: Tecnologías digitales, Tecnologías inteligentes, Universidad Inteligente, Adopción tecnológica.

Paper type: Research paper.

\section{Introduction}

Information is the most important asset for an organization. The study of the data generated corresponds to one of the main items for making assertive decisions. In the field of education, the data have the same importance. Its analysis allows generating predictions that can result in the improvement of the academic curriculum. With the advent of the Internet and the constant growth of technology, the scope of education has progressively increased. Today it is possible for people to access knowledge from remote locations through technology. As mentioned above, the arrival of the Internet and the evolution of technologies have allowed education to advance by leaps and bounds, but this does not guarantee that there are no challenges to overcome when implementing smart technologies.

The adoption and use of emerging technologies measure the degree of acceptance and application within an organization. Adoption and maturity are often closely related, as the entire organization follows the same 
approach. The adoption of technology in education organizations has influenced the educational model and the interactions between students and their academic environment to generate and share knowledge. The evolution of the new Smart University concept (Rico-Bautista et al., 2019; Rico-Bautista, 2019) allows a smart learning process that implies implementing an adaptive educational model using smart information technologies (Akhrif et al., 2019). This growth in adoption and use of digital tools has allowed education to progress progressively to satisfy the generation of students connected in the digital age to learn, inform themselves, and maintain contact with the outside world (Akhri et al., 2019). However, converting a traditional university into a Smart University is complex (Rico-Bautista, Medina-Cárdenas, et al., 2020). It requires the interaction of physical, human, and technological resources and the planning of strategies that guarantee this transformation.

According to Pornphol \& Tongkeo (2018), the following aspects are required to transition from a traditional university to a Smart University.

- Identification of the policies to develop guidelines that support University's administration.

- Reengineering or modification of the organizational structure, the administration process, the administration strategy, the follow-up and the improvement of the administration according to the concept of business process reengineering (BPR) through the application of a transformation strategy.

Technology is a fundamental tool that has contributed to the development of several sectors. However, its implementation cannot be taken lightly. Fundamental aspects related to security, privacy, availability of information, and Internet connection must be taken into account so that its use and implementation can have a beneficial result. The technologies in educational environments bring benefits in streamlining processes. However, it is important to emphasize that before implementing technology is important to perform a study that establishes the benefits and the negative aspects that the process can bring. Each technology brings special characteristics that adjust to the requirements of the environment. That is to say, in each intelligent technology, some elements are important at the moment of implementation.

This article is organized as follows: Section 2 presents the research methodology, describes what has been developed and published, as well as what is currently proposed, characterization of the selected technologies (Cloud Computing, Big Data, Artificial Intelligence, and the Internet of Things) for a smart university. Section 3 summarizes the adoption characteristics of smart technology. Section 4 describes the integration of these smart technologies in the University. Finally, Section 5 shows the conclusions.

\section{Research methodology}

Table 1 presents the methodology used in this study. They include the phases developed up to the catching evolution from the smart university, the characterization of smart technologies, the proposal of the adoption factors for each of them, and the integration.

Table 1. Components developed in this research

Component

1. Evolution and framework on the concept of smart university (RicoBautista, 2019).

\section{Description}

The smart university concept has evolved as follows:

- From smart city to smart university, published in (Maestre Góngora, 2015; Parra Valencia et al., 2017).

- Smart campus vs smart university, published in (Cerdeira Ferreira \& Mendes de Araujo, 2018; Sánchez-Torres et al., 2018).

- IoT as an emerging technology, published in (Parra Valencia et al., 2017; Rico-Bautista et al., 2019).

- Smart Technologies, published in (Rico-Bautista, MaestreGóngora, et al., 2020).

The methodology of the systematic review is based on those proposed by Snyder (2019) and the one proposed by Petersen et al. (2008), deepened in Revelo Sánchez et al. (2018). They were classified according to smart technologies: Artificial Intelligence, Big Data, Cloud technology adoption models (RicoBautista, Medina-Cárdenas, et al., 2020) 

al., 2020), see Table 2 .

3. Smart technology adoption factors proposal (Rico-Bautista, MedinaCárdenas, et al., 2020; Rico-

Bautista, Medina-Cardenas, et al., 2021; Rico-Bautista, MaestreGongora, et al., 2020).

4. Integration of smart technology adoption factors.
Each model classified by smart technology generates its advantages and disadvantages when fulfilling its function. The variables that manage to measure the degree of adoption better are generated. The factors associated with each of the defined variables are formulated (Choix et al., 2015; Frasquet Deltoro et al., 2012; López Cabrera et al., 2019; Martín García et al., 2014).

Each smart technology itself brings unique characteristics, which are adjusted to the requirements of the environment. That is to say, in each smart technology, some elements are important at the time of its adoption. The objective is to integrate them into a single proposal (RicoBautista, Collazos, et al., 2021).

Many models have been proposed to understand why users accept or use technologies (see Table 2). Of those that have emerged for the study of the adoption of technologies are TAM, UTAUT, UTAUT2, among others. According to the literature, the most used and validated model currently in organizations is TAM.

Table 2. Adoption models of Smart technologies

\begin{tabular}{l|l|l}
\multicolumn{2}{c}{ Smart technology } & \multicolumn{1}{c}{ Adoption model } \\
& TPB & (Abushakra \& Nikbin, 2019; Al-Momani et al., 2018, \\
& TAM & 2019; Brous et al., 2020; Das, 2019; Grandon et al., \\
& TRA & 2018; Kao et al., 2019; Mital et al., 2018; Nikbin \& \\
& UTAUT & Abushakra, 2019; Shaikh et al., 2019; Sivathanu, \\
& UTAUT2 & 2018). \\
\hline \multirow{3}{*}{ Cloud Computing } & UTAUT2 & (Al-Ruithe et al., 2017; Arpaci, 2017; Nasir \& Niazi, \\
& TAM & 2011; Nikolopoulos \& Likothanassis, 2017; Njenga \\
& UTAUT & et al., 2019; Palos-Sanchez et al., 2019; Pinheiro et \\
& al., 2014; Priyadarshinee et al., 2017; Raut et al., \\
\hline \multirow{2}{*}{ Big Data and Artificial Intelligence } & TAM & 2018; Sabi et al., 2016; Vasudavan et al., 2018). \\
\hline & UTAUT & (Shorfuzzaman et al., 2019; Surbakti et al., 2020).
\end{tabular}

\section{Adoption of smart technology}

\subsection{Adoption of IoT}

The arrival of the Internet has driven the growing use of digital tools, in all environments, especially in education, becoming a growing challenge for all institutions, which are focused on permanently establishing high performance through the use of tools that are at the forefront. The development of digital processes, including Internet of Things (IoT) applications, is essential for the required transformation of the industry (Barrientos-Avendaño \& Areniz-Arévalo, 2019; Guerrero \& Rico-Bautista, 2020). The impact of IoT adoption is mainly related to the data obtained (Brous et al., 2020). It is sought that many of these can be taken in real-time (Abushakra \& Nikbin, 2019).

This technology enables companies to adopt new data-driven strategies and handle global competitive pressure more easily (Mourtzis et al., 2016). For the proposed factors, the technology acceptance model (TAM) is taken as a basis. This case raises four fundamental aspects: perceived utility, perceived ease of use, attitude towards use, and intention towards use. To adopt this technology, the application in higher education environments is emphasized (see Figure 1). 

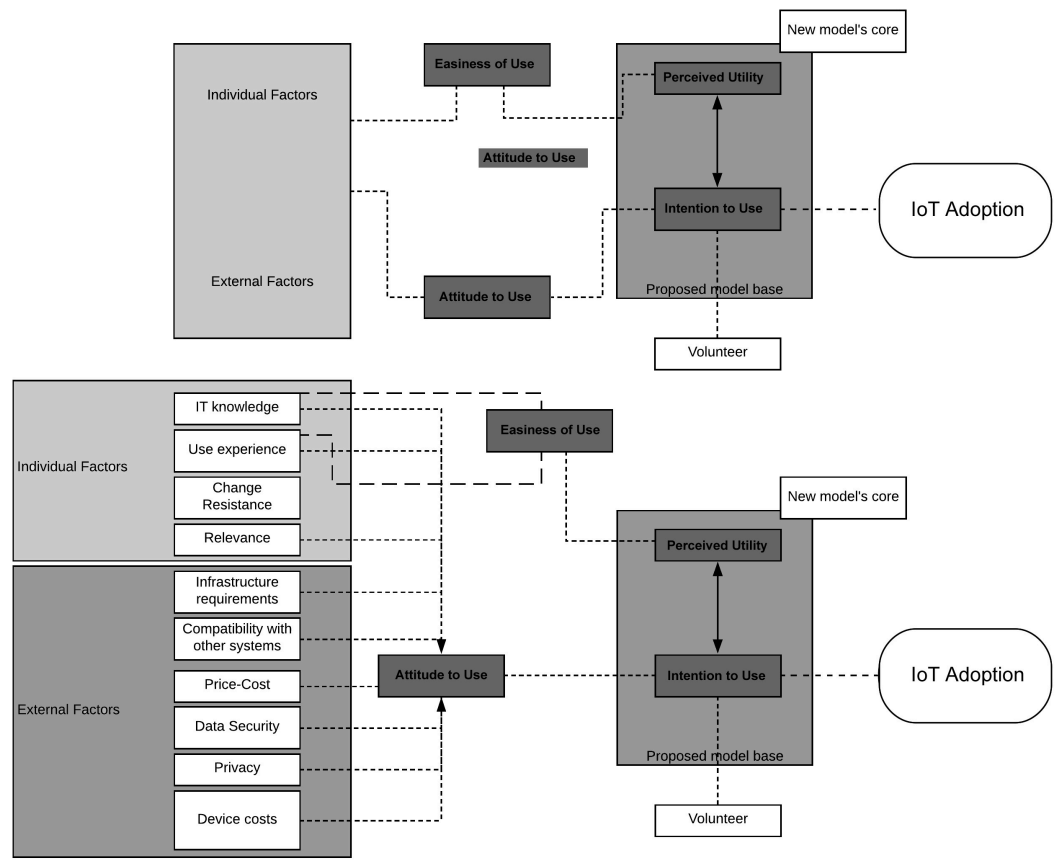

Figure 1. Adoption factors for proposed IoT technology

\subsection{Adoption of Cloud Computing}

Managing, storing, and sharing data quickly and easily from anywhere in the world with an Internet connection has become of vital importance (Pinheiro et al., 2014; Xu, 2020). The main benefits include scalability, resilience, flexibility, efficiency, and outsourcing of non-essential activities. It is one of the most advanced related digital technologies essential for optimal and quality operation focused on improving interoperability and flexibility in the processes of today's organizations (Y. C. Medina-Cárdenas \& RicoBautista, 2016; Y. Medina-Cárdenas \& Rico-Bautista, 2008, 2009; Medina Cárdenas et al., 2016; Vasudavan et al., 2018). As it is implemented, it also creates challenges in areas such as data governance, manageability, monitoring, reliability, availability, and security (Raut et al., 2018). It offers unique capabilities for enterprises, which can quickly move to a competitive position and take advantage of servicebased IT solutions at a low cost; likewise, to globalize your processes quickly and distributed business operations become easier to perform (El-Gazzar et al., 2016).

According to the tools for measuring the level of adoption of smart technologies in information systems, the non-adoption of this type of technology is mainly due to several factors, one of them is the Perceived Utility Factor (PU): the degree in that a person believes that using a particular system would improve their job performance; the other factor is perceived ease of use (PEOU); the degree to which a person believes that using a particular system would be effortless (Cecil, 2018). The adoption of cloud computing in education has the potential to improve knowledge management, being the sector that adopts its services the most, followed by telecommunications (Al-Ruithe et al., 2017). To conclude, the factors that affect its adoption cross technological, organizational, and environmental contexts (Nikolopoulos \& Likothanassis, 2017). These three configurations involve stakeholders including, but not limited to, cloud service providers, end-users, corporate leaders, regulatory authorities, and competitors on the market scene (Njenga et al., 2019). The key aspects to take into account when adopting cloud computing refer to trust and IT security (Priyadarshinee et al., 2017) (see Figure 2), taking as a point of reference some elements of the TAM model. 


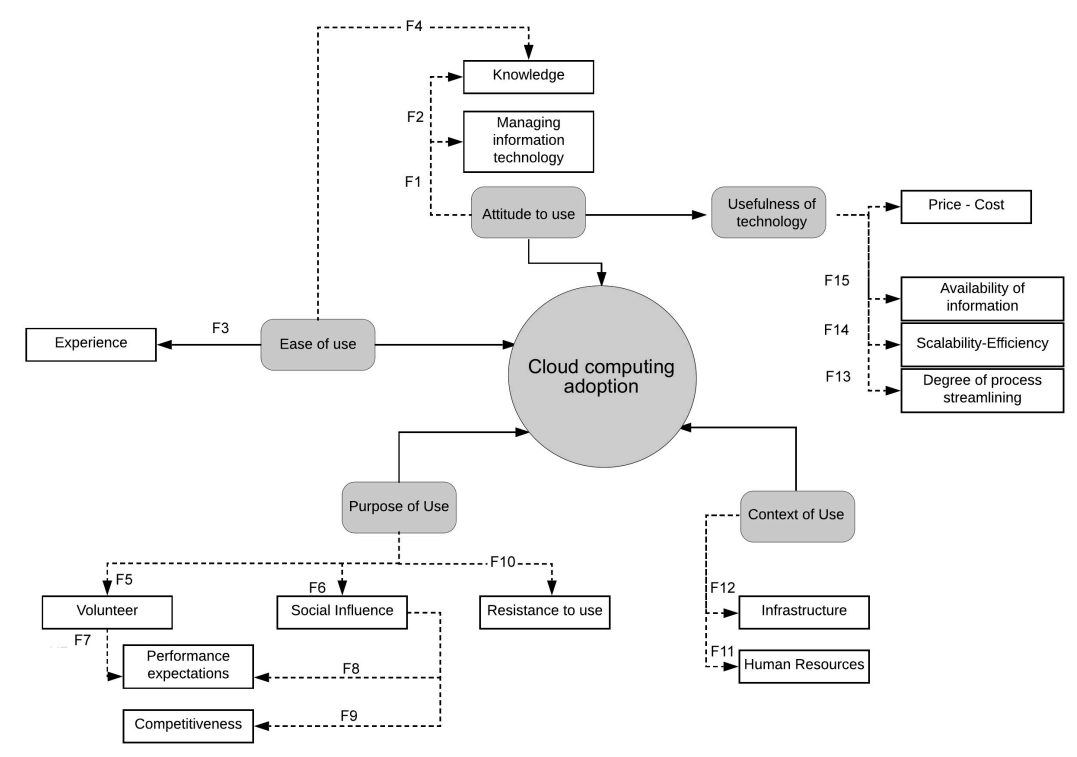

Figure 2. Proposed adoption factors for Cloud Computing technology

\subsection{Adoption of Big Data}

Big data is having a huge impact in various fields, including commerce, education, healthcare, and finance. The education sector is one of which generates more data, and this is because the internet is a fundamental tool for students, necessary for their learning (Hao et al., 2018). The result of the analysis of data on student academic achievement can present the future career, area of interest, and educational curriculum for a specific student, and can provide individualized learning given the fact that it individually provides learning methods and personalized information (Kim \& Ahn, 2016).

Sophisticated data analysis techniques are required to handle the complexity of learning and analyze a large number of data sets to improve the learning experiences of students, resulting in its adoption of efficient processing (Shorfuzzaman et al., 2019). In organizations, data collection and analysis are a fundamental element to make good decisions, focused on improving the general performance of the company, helping to evaluate the work performance of each worker. They should focus on several issues when implementing this technology, one of which is the quality of the data (Ramos et al., 2015). For it to be successful in organizations, regulatory and ethical challenges must also be addressed, these include privacy concerns (Hamilton \& Sodeman, 2020; Wu et al., 2017). Big data is a complex phenomenon, and understanding the technical, organizational, and human factors that contribute to its effective use are key to providing organizations with guidance to improve the results of their large projects (Surbakti et al., 2020). Data has become so important that data analysis is a critical competitive asset and central element in the decision-making process of various industries (Barrientos-Avendaño, Coronel-Rojas, et al., 2020). In the case of the implementation of Big Data in higher education institutions, the factors to measure its level of adoption are associated in different ways (Rico-Bautista, Medina-Cardenas, et al., 2020). See Figure 3. 


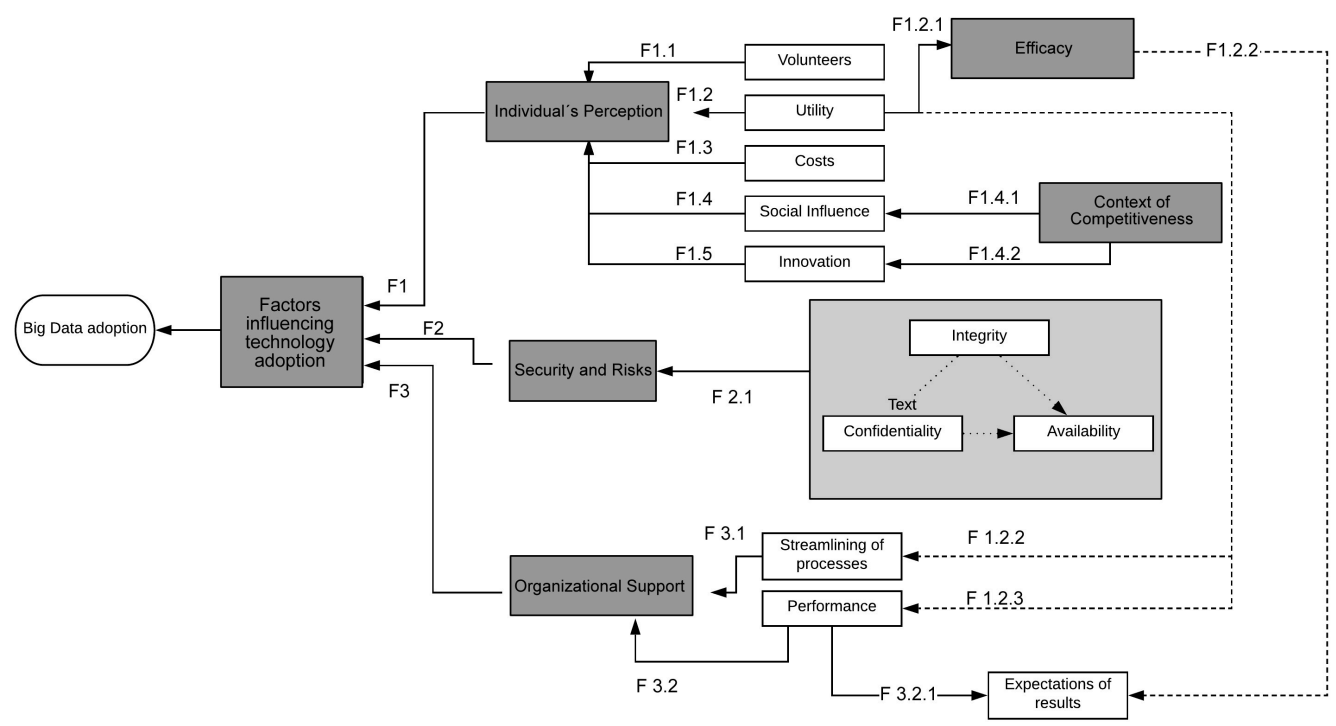

Figure 3. Proposed adoption factors for Big Data technology

\subsection{Adoption of IA}

The processing of Big Data through Artificial Intelligence (AI) can contribute greatly to the urban fabric, the dimensions of sustainability and habitability should not be overlooked in favor of technological (Allam \& Dhunny, 2019). Machine intelligence and robotics with deep learning capabilities have created disruptive and enabling effects in business, government, education, and society (Goralski \& Tan, 2020).

Research teaching fits the requirements and needs of a smart learning environment, contributes to creating innovative trends through the use of data in the application of new technologies, which support the creation of smart services, meeting the needs of students. To implement this, the system requires a set of smart technologies, methods, hardware, and software components, which increases the constraints related to adaptation to the context, data analysis, prediction, and recommendation within a learning environment (Akhrif et al., 2019). Universities, in particular, have served as an ideal platform to showcase smart applications to promote smart campuses. Today, it is common to see projects dedicated to promoting smart environments capable of analyzing data and making decisions based on the captured data, using smart tools and state-of-the-art technologies (Sayed et al., 2020).

In the education sector, this technology can help decipher the difficulties of students and understand how to help them, enhance the imagination of a community and design a new educational experience (Chassignol et al., 2018). Various AI techniques have been used in adaptive education systems (BarrientosAvendaño, Areniz-Arevalo, et al., 2020). See Figure 4. 


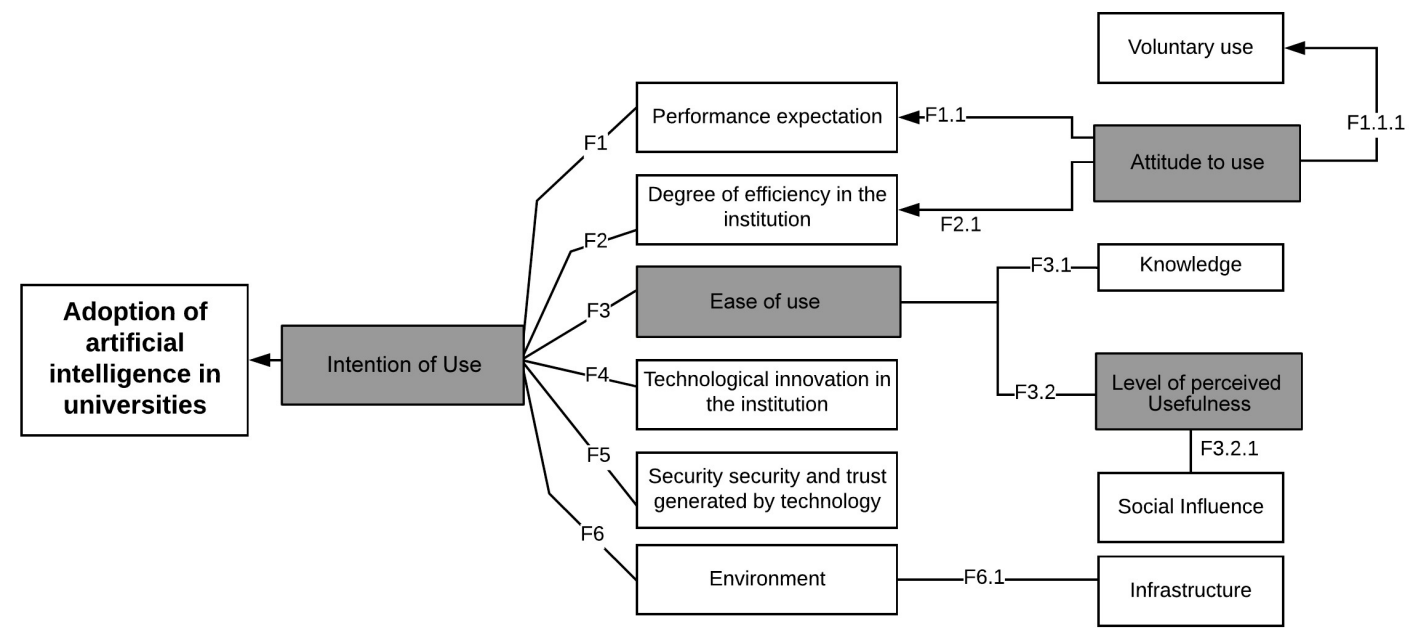

Figure 4. Proposed factors for AI technology

\section{Adoption factors of smart university technologies}

Education is a fundamental pillar in the intellectual development of each individual. In many institutions, it is taught traditionally, with a methodology applied to a group of students alike. With the arrival of the technological era, a series of tools have been proposed to individualize this process according to the needs of each individual, managing to establish a specific and independent educational pace for each student. When a university proposes the use of smart technologies, it not only stays at the forefront but also becomes a leading institution, generator of emerging technologies and becomes a reference for other institutions in the management of technological trends (Choix et al., 2015; Frasquet Deltoro et al., 2012; López Cabrera et al., 2019; Luzardo Briceño et al., 2017; Martín García et al., 2014). A Smart university is the set of technological tools that, when applied, improve the way processes and activities are carried out. Among the tools is the internet of things that allows the integration various networks and heterogeneous sensor devices in a smart system. Implementing it shows several important challenges, such as effective management of material and structural resources in the organization.

The integration of each smart technology has its center in one of the elements extracted from TAM (see Figure 5): Intention towards use. 


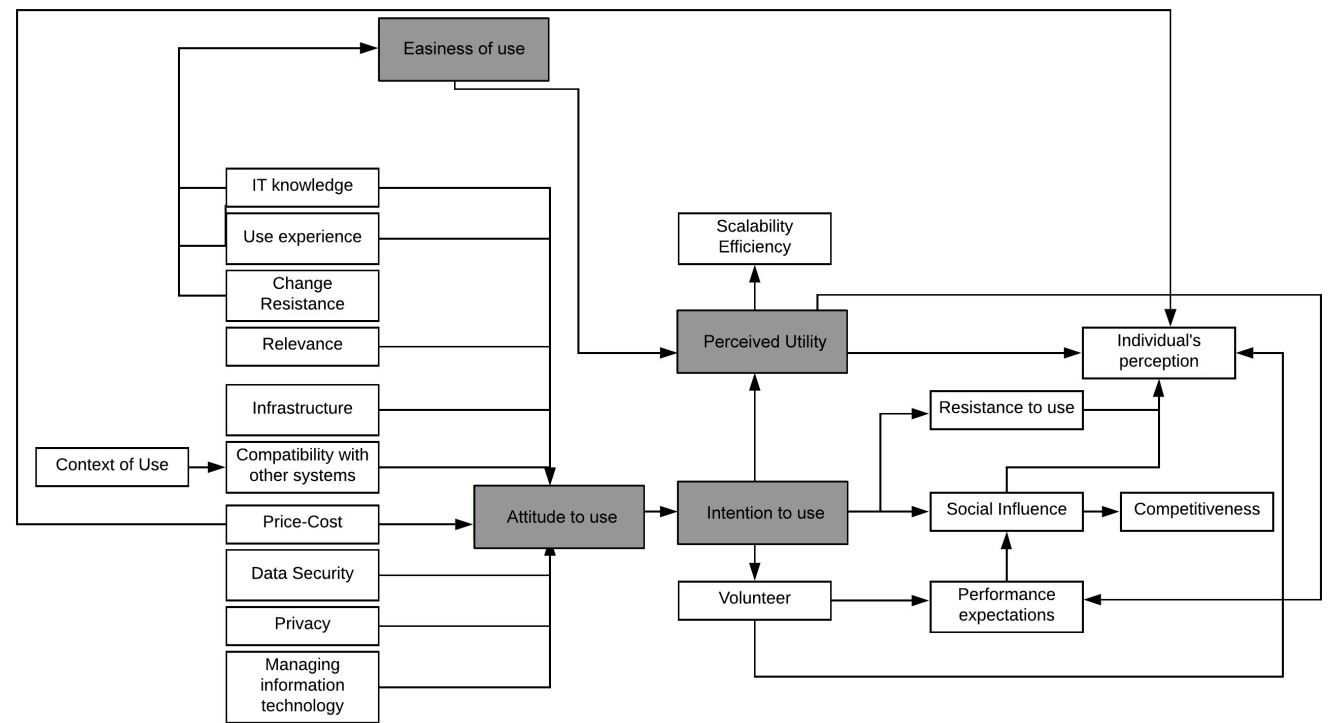

Figure 5. Integration of the adoption factors smart technology proposed for universities

From this item, four aspects of vital importance emerge, which we will deal with below:

- Perceived utility-Perception of the institution. It has to do with the perceptions that had in this case of smart technology. They are closely related. If there is utility, the perception will be good. Therefore, the social influence in the circle surrounding it will improve, thus allowing it to act for the benefit of the adoption of technology.

- Social influence-Competitiveness. Competitiveness is an element that makes us reappear and enter into the use of new technologies. By mixing with social influence, it can act both positively and negatively.

- Social influence-Performance expectations. The latter directly affects social influence and acts in a similar way to the previous item.

- Intention of use voluntary. The results obtained from the voluntary adoption of technology positively impact the intention of use. It has to do with the perception generated by the user.

- Intention towards the utility perceived by the use. The utility directly influences the intention to use. That is, if a good utility is perceived, the intention to use it will increase.

- Attitude towards use-Intention towards use. The attitude comes from the incidence of several factors, but the intention influences the attitude.

- Attitude towards use-knowledge. The attitude towards use is directly proportional to the degree of knowledge that one has of a technology.

- Attitude towards use-Experience. Experience acts as a positive factor when adopting technology.

- Attitude towards use-Resistance to change. If there is resistance to change, the attitude generated will be negative, and the technology's adoption will be significantly affected.

- Attitude towards use-Infrastructure-Context. These are elements that are part of the physical environment. The infrastructure in some technologies is necessary to establish good performance criteria.

- Attitude towards user-Compatibility with other systems. In some institutions, there are tools implemented, and when making use of new technologies, these tools generate conflicts and a bad user experience

- Attitude towards use-Price. Cost it seeks to obtain a beneficial attitude towards reasonable costs.

- Attitude towards the use-data security and privacy. Handling that technology gives to the information, these items are related, and all mentioned aspects have to do directly with the information. The attitude towards the use is favorable as long as it complies with the previous items. 
Premises:

- The more technology knowledge will be easier to use, and therefore the attitude towards its use will be favorable, thus increasing the degree of adoption.

- The privacy of information is a favorable aspect given the attitude of the use of new technology.

- Knowledge gives way to ease of use, and therefore the perceived usefulness will be greater.

- High-performance expectations serve to generate more significant social influence.

- Positive social influence improves the individual's perception of new technology.

- The price to cost ratio is closely related to the individual's perception.

- Resistance to use negatively affects the intention to use.

- If performance expectations are met, the greater the perceived utility.

- Resistance to change has a negative influence on ease of use.

\section{Conclusions}

The new technologies bring benefits, allowing to solve the needs in a community, but the process of its implementation, is something that cannot be done lightly, the steps to follow must be studied and a strategic planning must be established to help the organizations to adapt to the technology in the best way; in many cases the viability in specific environments must be taken into account and it is very important to be able to recognize when this process will not bring benefits; but if on the contrary, the viability studies give positive results, the recommendation is to begin little by little with the adoption of the technology, to use it in areas and to study its operation. The adoption of smart technologies is becoming an increasingly common object of study in research work. The implementation of emerging technologies in universities must take into account aspects related to security, privacy, availability of information, and internet connection.

For the smart Cloud Computing technology, the central value is in the management of the information, the universities require elements that improve, expedite, and safeguard the information and have it at the moment which it is necessary; Implementing this technology not only foresees these needs, but also gives an added value of keeping all the information centralized in one place, for example with this technology, a university can create its own private cloud within its own infrastructure and thus achieve satisfy all the aforementioned requirements, it is important to emphasize the orientation that the institution has when wanting to implement this new technology that brings with it many benefits, but which in turn requires personnel who know its operation.

Artificial intelligence is focused on the intention of use, in which many other aspects that influence the adoption of the technology fall, it is for this reason that before implementing it analysis is necessary to see the feasibility of this action. This technology brings many benefits in higher education environments, we can speak of smart tutors, which based on algorithms can create a pattern where the requirements of each student, in particular, are established, in other words, what allows us to create personalized teaching, with permanent support; To this is added that each teacher in the area can be aware of the development of work with their students, managing to establish an improvement in terms of learning techniques.

For the particular case of Big Data, 3 main factors revolve in terms of its adoption, the perception of the institution before the adoption of the technology, is important because the institution must have a good perception value to have good results in the implementation of technology. The second and most important aspect has to do with risks and security, practically this technology is based on the management and administration of information, for this reason, this subsection represents a fundamental value, it must be guaranteed for a university to trust that using this technology could have a good analysis of your information; and finally, institutional support, which is related to the functionality of the technology already implemented in the institution; For example, a university expects high performance that has to do with the level of utility and in turn with the streamlining of processes. 


\section{Statement of conflict of interest}

The authors declared no potential conflicts of interest with respect to the research, authorship and/or publication of this article.

\section{Funding}

Dewar Rico-Bautista's doctoral studies program with the project "Maturity model of adoption of Information Technologies for universities: An approach from the Smart University perspective" is supported by the Universidad Francisco de Paula Santander Ocaña in the teacher training plan of the Department of Systems and Informatics.

\section{ORCID iD}

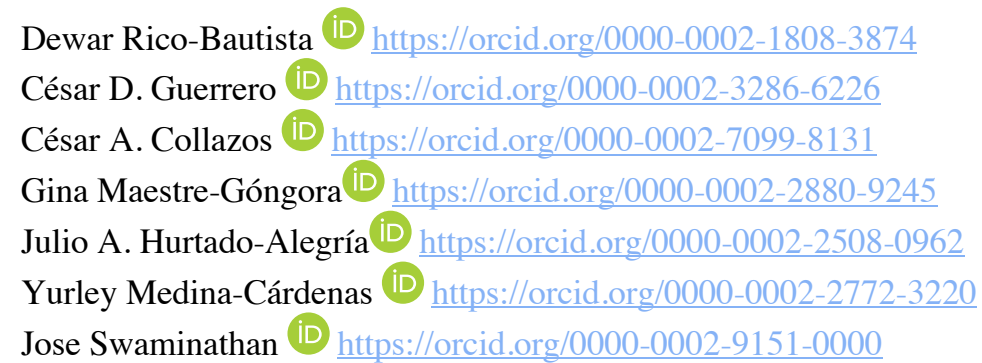

\section{Referencias}

Abushakra, A., \& Nikbin, D. (2019). Knowledge Management in Organizations (L. Uden, I.-H. Ting, \& J. M. Corchado (eds.); Vol. 1027). Springer International Publishing. https://doi.org/10.1007/978-3-030-21451-7

Akhrif, O., El bouzekri el idrissi, Y., \& Hmina, N. (2019). Enabling Smart Collaboration with Smart University Services. In A. Emrouznejad (Ed.), Proceedings of the 3rd International Conference on Computer Science and Application Engineering - CSAE 2019 (pp. 1-6). ACM Press. https://doi.org/10.1145/3331453.3361311

Al-Momani, A. M., Mahmoud, M. A., \& Ahmad, M. S. (2018). Factors that Influence the Acceptance of Internet of Things Services by Customers of Telecommunication Companies in Jordan. Journal of Organizational and End User Computing, 30(4), 51-63. https://doi.org/10.4018/JOEUC.2018100104

Al-Momani, A. M., Mahmoud, M. A., \& Ahmad, M. S. (2019). A Review of Factors Influencing Customer Acceptance of Internet of Things Services. International Journal of Information Systems in the Service Sector, 11(1), 54-67. https://doi.org/10.4018/IJISSS.2019010104

Al-Ruithe, M., Benkhelifa, E., \& Hameed, K. (2017). Current State of Cloud Computing Adoption - An Empirical Study in Major Public Sector Organizations of Saudi Arabia (KSA). Procedia Computer Science, 110, 378-385. https://doi.org/10.1016/j.procs.2017.06.080

Allam, Z., \& Dhunny, Z. A. (2019). On big data, artificial intelligence and smart cities. Cities, 89(January), 80-91. https://doi.org/10.1016/j.cities.2019.01.032

Arpaci, I. (2017). Antecedents and consequences of cloud computing adoption in education to achieve knowledge management. Computers in Human Behavior, 70, 382-390. https://doi.org/10.1016/j.chb.2017.01.024

Barrientos-Avendaño, E., \& Areniz-Arévalo, Y. (2019). Universidad inteligente: Oportunidades y desafíos desde la Industria 4.0. Revista Ingenio UFPSO, 16(1). https://doi.org/10.22463/2011642X.2343

Barrientos-Avendaño, E., Areniz-Arevalo, Y., Coronel-Rojas, L. A., Cuesta-Quintero, F., \& Rico-Bautista, D. (2020). Modelo de incursión en la industria 4.0 aplicado a la compañía alimenticia tu pan gourmet SAS: Estrategia para el renacer en la pandemia ocasionada por COVID-19 (SARS-CoV-2). RISTI - Revista Iberica de Sistemas e Tecnologias de Informacao, 2020(E34), 436-449.

Barrientos-Avendaño, E., Coronel-Rojas, L. A., Cuesta-Quintero, F., \& Rico-Bautista, D. (2020). Sistema de administración de ventas tienda a tienda: Aplicando técnicas de inteligencia artificial. RISTI - Revista Iberica de Sistemas e Tecnologias de Informacao, 2020(E27), 677-689.

Brous, P., Janssen, M., \& Herder, P. (2020). The dual effects of the Internet of Things (IoT): A systematic review of 
the benefits and risks of IoT adoption by organizations. International Journal of Information Management, 51(May), 101952. https://doi.org/10.1016/j.ijinfomgt.2019.05.008

Cecil, J. (2018). A Collaborative Manufacturing Approach supporting adoption of IoT Principles in Micro Devices Assembly. Procedia Manufacturing, 26, 1265-1277. https://doi.org/10.1016/j.promfg.2018.07.141

Cerdeira Ferreira, F. H., \& Mendes de Araujo, R. (2018). Campus Inteligentes: Conceitos, aplicações, tecnologias e desafios. Relatórios Técnicos Do DIA/UNIRIO, $11(1), \quad 4$-19. http://www.seer.unirio.br/index.php/monografiasppgi/article/view/7147

Chassignol, M., Khoroshavin, A., Klimova, A., \& Bilyatdinova, A. (2018). Artificial Intelligence trends in education: a narrative overview. Procedia Computer Science, 136, 16-24. https://doi.org/10.1016/j.procs.2018.08.233

Choix, R. A., Perez, R. R., \& Parra, M. E. L. (2015). Factores determinantes en la adopción de tecnologías de información (TI) en las pymes. VinculaTégica EFAN, 1(1), 806-828. http://eprints.uanl.mx/17205/1/44.pdf

Das, S. (2019). The Early Bird Catches the Worm - First Mover Advantage through IoT Adoption for Indian Public Sector Retail Oil Outlets. Journal of Global Information Technology Management, 22(4), 280-308. https://doi.org/10.1080/1097198X.2019.1679588

El-Gazzar, R., Hustad, E., \& Olsen, D. H. (2016). Understanding cloud computing adoption issues: A Delphi study approach. Journal of Systems and Software, 118, 64-84. https://doi.org/10.1016/j.jss.2016.04.061

Frasquet Deltoro, M., Mollá Descals, A., \& Eugenia Ruiz Molina, M. (2012). Factores determinantes y consecuencias de la adopción del comercio electrónico B2C:una comparativa internacional. Estudios Gerenciales, 28(123), 101-120. https://doi.org/10.1016/S0123-5923(12)70207-3

Goralski, M. A., \& Tan, T. K. (2020). Artificial intelligence and sustainable development. The International Journal of Management Education, 18(1), 100330. https://doi.org/10.1016/j.ijme.2019.100330

Grandon, E. E., Ibarra, A. A., Guzman, S. A., Ramirez-Correa, P., \& Alfaro-Perez, J. (2018). Internet of Things: Factors that influence its adoption among Chilean SMEs. 2018 13th Iberian Conference on Information Systems and Technologies (CISTI), 1-6. https://doi.org/10.23919/CISTI.2018.8399183

Guerrero, C. D., \& Rico-Bautista, D. (2020). Centro de Excelencia y Apropiación en Internet de las Cosas: Una apuesta a la competitividad desde alianzas entre gobierno, academia y sector productivo. RISTI - Revista Iberica de Sistemas e Tecnologias de Informacao, 2020(E28), 615-628.

Hamilton, R. H., \& Sodeman, W. A. (2020). The questions we ask: Opportunities and challenges for using big data analytics to strategically manage human capital resources. Business Horizons, 63(1), 85-95. https://doi.org/10.1016/j.bushor.2019.10.001

Hao, W., Huang, Z., \& Shi, L. (2018). Research on college students' ideological and political education and daily performance evaluation model based on big data. Journal of Advanced Oxidation Technologies, 21(2).

Kao, Y.-S., Nawata, K., \& Huang, C.-Y. (2019). An Exploration and Confirmation of the Factors Influencing Adoption of IoT-Based Wearable Fitness Trackers. International Journal of Environmental Research and Public Health, 16(18), 3227. https://doi.org/10.3390/ijerph16183227

Kim, Y. H., \& Ahn, J. (2016). A Study on the Application of Big Data to the Korean College Education System. Procedia Computer Science, 91(Itqm 2016), 855-861. https://doi.org/10.1016/j.procs.2016.07.096

López Cabrera, M. V., Hernandez-Rangel, E., Mejía Mejía, G. P., \& Cerano Fuentes, J. L. (2019). Factores que facilitan la adopción de tecnología educativa en escuelas de medicina. Educación Médica, 20, 3-9. https://doi.org/10.1016/j.edumed.2017.07.006

Luzardo Briceño, M., Sandia Saldivia, B. E., Aguilar Jiménez, A. S., Macias Martínez, M., \& Herrera Díaz, J. (2017). Factores que influyen en la adopción de las Tecnologías de Información y Comunicación por parte de las universidades. Dimensión Enseñanza-Aprendizaje. Educere, 21(68), 143-153.

Maestre Góngora, G. P. (2015). Revisión de literatura sobre ciudades inteligentes: una perspectiva centrada en las TIC. INGENIARE, 19, 137. https://doi.org/10.18041/1909-2458/ingeniare.19.531

Martín García, A. V., García del Dujo, Á., \& Muñoz Rodríguez, J. M. (2014). Factores determinantes de adopción de blended learning en educación superior. Adaptación del modelo UTAUT. Educación XX1, 17(2). https://doi.org/10.5944/educxx1.17.2.11489

Medina-Cárdenas, Y. C., \& Rico-Bautista, D. (2016). Strategic alignment under a technology management organizational approach: ITIL \& ISO 20000. Revista Tecnura, 20(1), 82-94. https://doi.org/10.14483/22487638.11681

Medina-Cárdenas, Y., \& Rico-Bautista, D. (2008). Model of Administration of Services for the Universidad of Pamplona: ITIL. Scientia Et Technica Scientia et Technica Año XIV, 14(39), 314-319.

Medina-Cárdenas, Y., \& Rico-Bautista, D. (2009). Modelo de gestión basado en el ciclo de vida del servicio de la Biblioteca de Infraestructura de Tecnologías de Información (ITIL). Revista Virtual Universidad Católica Del Norte, 27, 1-21.

Medina Cárdenas, Y.C., Areniz Arévalo, Y., \& Rico Bautista,D. (2016). Modelo estratégico para la gestión tecnológica en la organización: plan táctico de la calidad (ITIL \& ISO 20000). In Fondo editorial ITM (Vol. 1). Instituto Tecnológico Metropolitano. https://doi.org/10.22430/9789585414006

Mital, M., Chang, V., Choudhary, P., Papa, A., \& Pani, A. K. (2018). Adoption of Internet of Things in India: A test of competing models using a structured equation modeling approach. Technological Forecasting and Social Change, 136,339-346. https://doi.org/10.1016/j.techfore.2017.03.001

Mourtzis, D., Vlachou, E., \& Milas, N. (2016). Industrial Big Data as a Result of IoT Adoption in Manufacturing. 
Procedia CIRP, 55, 290-295. https://doi.org/10.1016/j.procir.2016.07.038

Nasir, U., \& Niazi, M. (2011). Cloud computing adoption assessment model (CAAM). Proceedings of the 12th International Conference on Product Focused Software Development and Process Improvement - Profes '11, 44(0), 34-37. https://doi.org/10.1145/2181101.2181110

Nikbin, D., \& Abushakra, A. (2019). Internet of Things Adoption: Empirical Evidence from an Emerging Country. In Communications in Computer and Information Science (pp. 348-352). https://doi.org/10.1007/978-3-03021451-7_30

Nikolopoulos, F., \& Likothanassis, S. (2017). Using UTAUT2 for cloud computing technology acceptance modeling. Proceedings of the Second International Conference on Internet of Things, Data and Cloud Computing, March, 1-6. https://doi.org/10.1145/3018896.3025153

Njenga, K., Garg, L., Bhardwaj, A. K., Prakash, V., \& Bawa, S. (2019). The cloud computing adoption in higher learning institutions in Kenya: Hindering factors and recommendations for the way forward. Telematics and Informatics, 38(May), 225-246. https://doi.org/10.1016/j.tele.2018.10.007

Palos-Sanchez, P., Reyes-Menendez, A., \& Saura, J. R. (2019). Modelos de Adopción de Tecnologías de la Información y Cloud Computing en las Organizaciones. Información Tecnológica, 30(3), 3-12. https://doi.org/10.4067/S0718-07642019000300003

Parra Valencia, J. A., Guerrero, C. D., \& Rico Bautista, D. (2017). IOT: una aproximación desde ciudad inteligente a universidad inteligente. Revista Ingenio, 13(1), 9-20. https://doi.org/10.22463/2011642X.2128

Petersen, K., Feldt, R., Mujtaba, S., \& Mattsson, M. (2008). Systematic Mapping Studies in Software Engineering. 12th International Conference on Evaluation and Assessment in Software Engineering, EASE 2008. https://doi.org/10.14236/ewic/EASE2008.8

Pinheiro, P., Aparicio, M., \& Costa, C. (2014). Adoption of cloud computing systems. Proceedings of the International Conference on Information Systems and Design of Communication - ISDOC '14, 127-131. https://doi.org/10.1145/2618168.2618188

Pornphol, P., \& Tongkeo, T. (2018). Transformation from a traditional university into a smart university. Proceedings of the 6th International Conference on Information and Education Technology, 144-148. https://doi.org/10.1145/3178158.3178167

Priyadarshinee, P., Raut, R. D., Jha, M. K., \& Gardas, B. B. (2017). Understanding and predicting the determinants of cloud computing adoption: A two staged hybrid SEM - Neural networks approach. Computers in Human Behavior, 76, 341-362. https://doi.org/10.1016/j.chb.2017.07.027

Ramos, T. G., Machado, J. C. F., \& Cordeiro, B. P. V. (2015). Primary Education Evaluation in Brazil Using Big Data and Cluster Analysis. Procedia Computer Science, 55(Itqm), 1031-1039. https://doi.org/10.1016/j.procs.2015.07.061

Raut, R. D., Priyadarshinee, P., Gardas, B. B., \& Jha, M. K. (2018). Analyzing the factors influencing cloud computing adoption using three stage hybrid SEM-ANN-ISM (SEANIS) approach. Technological Forecasting and Social Change, 134(July 2017), 98-123. https://doi.org/10.1016/j.techfore.2018.05.020

Revelo Sánchez, O., Collazos Ordoñez, C. A., \& Jiménez Toledo, J. A. (2018). La gamificación como estrategia didáctica para la enseñanza/aprendizaje de la programación: un mapeo sistemático de literatura. Lámpsakos, 1(19), 31-46. https://doi.org/10.21501/21454086.2347

Rico-Bautista, D. (2019). Conceptual framework for smart university. Journal of Physics: Conference Series, 1409, 012009. https://doi.org/10.1088/1742-6596/1409/1/012009

Rico-Bautista, D., Collazos, C. A., Guerrero, C. D., Maestre-Gongora, G., \& Medina-Cárdenas, Y. (2021). Latin American Smart University: Key Factors for a User-Centered Smart Technology Adoption Model. In Sustainable Intelligent Systems (pp. 161-173). https://doi.org/10.1007/978-981-33-4901-8_10

Rico-Bautista, D., Maestre-Gongora, G., \& Guerrero, C. D. (2020). Smart University:IoT adoption model. 2020 Fourth World Conference on Smart Trends in Systems, Security and Sustainability (WorldS4), 821-826. https://doi.org/10.1109/WorldS450073.2020.9210369

Rico-Bautista, D., Maestre-Góngora, G. P., \& Guerrero, C. D. (2020). Smart university: Characterization of the current situation of intelligent technologies, based on two case studies [Caracterización de la situación actual de las tecnologías inteligentes para una universidad inteligente en Colombia/latinoamérica]. RISTI - Revista Iberica de Sistemas e Tecnologias de Informacao, 2020(E27), 484-501.

Rico-Bautista, D., Medina-Cardenas, Y., Areniz-Arevalo, Y., Barrientos-Avendano, E., Maestre-Gongora, G., \& Guerrero, C. D. (2020). Smart University: Big Data adoption model. 2020 9th International Conference On Software Process Improvement (CIMPS), 52-60. https://doi.org/10.1109/CIMPS52057.2020.9390151

Rico-Bautista, D., Medina-Cárdenas, Y., Coronel-Rojas, L. A., Cuesta-Quintero, F., Barrientos-Avendaño, E., García León, R. A., \& Maestre-Góngora, G. P. (2020). Universidad inteligente: Mapa estratégico desde la adopción de tecnología. RISTI - Revista Iberica de Sistemas e Tecnologias de Informacao, 2020(E28), 711-724. http://www.risti.xyz/issues/ristie28.pdf

Rico-Bautista, D., Medina-Cardenas, Y., Coronel-Rojas, L. A., Cuesta-Quintero, F., Maestre-Gongora, G., \& Guerrero, C. D. (2021). Smart University: Key Factors for an Artificial Intelligence Adoption Model. In M. V García, F. Fernández-Peña, \& C. Gordón-Gallegos (Eds.), Advances and Applications in Computer Science, Electronics and Industrial Engineering (Vol. 1307, pp. 153-166). Springer Singapore. https://doi.org/10.1007/978-981-334565-2_10 
Rico-Bautista, D., Medina-Cárdenas, Y., \& Guerrero, C. D. (2019). Smart University: A Review from the Educational and Technological View of Internet of Things. In M. Paredes, C. Ferras, \& A. Rocha (Eds.), International Conference on Information Technology and Systems, ICITS 2019 (Vol. 918, pp. 427-440). Springer Verlag. https://doi.org/10.1007/978-3-030-11890-7_42

Sabi, H. M., Uzoka, F. E., Langmia, K., \& Njeh, F. N. (2016). Conceptualizing a model for adoption of cloud computing in education. International Journal of Information Management, 36(2), 183-191. https://doi.org/10.1016/j.ijinfomgt.2015.11.010

Sánchez-Torres, B., Rodríguez-Rodríguez, J. A., Rico-Bautista, D., \& Guerrero, C. D. (2018). Smart Campus: Trends in cybersecurity and future development. Revista Facultad de Ingeniería, 27(47), 93-101. https://doi.org/10.19053/01211129.v27.n47.2018.7807

Sayed, A. El, Suad, Š., Fuad, Ć., \& Novali, A. (2020). New Technologies, Development and Application II. In I. Karabegović (Ed.), Springer Nature Switzerland (Vol. 76). Springer International Publishing. https://doi.org/10.1007/978-3-030-18072-0

Shaikh, H., Khan, M. S., Mahar, Z. A., Anwar, M., Raza, A., \& Shah, A. (2019). A Conceptual Framework for Determining Acceptance of Internet of Things (IoT) in Higher Education Institutions of Pakistan. 2019 International Conference on Information Science and Communication Technology (ICISCT), 1-5. https://doi.org/10.1109/CISCT.2019.8777431

Shorfuzzaman, M., Hossain, M. S., Nazir, A., Muhammad, G., \& Alamri, A. (2019). Harnessing the power of big data analytics in the cloud to support learning analytics in mobile learning environment. Computers in Human Behavior, 92, 578-588. https://doi.org/10.1016/j.chb.2018.07.002

Sivathanu, B. (2018). Adoption of internet of things (IOT) based wearables for healthcare of older adults - a behavioural reasoning theory (BRT) approach. Journal of Enabling Technologies, 12(4), 169-185. https://doi.org/10.1108/JET-12-2017-0048

Snyder, H. (2019). Literature review as a research methodology: An overview and guidelines. Journal of Business Research, 104,333-339. https://doi.org/10.1016/j.jbusres.2019.07.039

Surbakti, F. P. S., Wang, W., Indulska, M., \& Sadiq, S. (2020). Factors influencing effective use of big data: A research framework. Information \& Management, 57(1), 103146. https://doi.org/10.1016/j.im.2019.02.001

Vasudavan, H., Shanmugam, K., \& Ahmada, H. A. (2018). User Perceptions in Adopting Cloud Computing in Autonomous Vehicle. Proceedings of the 6th International Conference on Information Technology: IoT and Smart City - ICIT 2018, 151-156. https://doi.org/10.1145/3301551.3301583

Wu, J., Li, H., Liu, L., \& Zheng, H. (2017). Adoption of big data and analytics in mobile healthcare market: An economic perspective. Electronic Commerce Research and Applications, 22, 24-41. https://doi.org/10.1016/j.elerap.2017.02.002

Xu, H. (2020). Application of Cloud Computing Information Processing System in Network Education. In J. H. Abawajy, K. Choo, R. Islam, Z. Xu, \& M. Atiquzzaman (Eds.), International Conference on Applications and Techniques in Cyber Intelligence, ATCI 2019 (Vol. 1017, pp. 1809-1815). Springer Verlag. https://doi.org/10.1007/978-3-030-25128-4_238 